\title{
Korelasi Antara Komunikasi dan Pendidikan
}

\author{
Tomi Hendra, Siti Saputri \\ Institut Agama Islam Negeri (IAIN) Bukittinggi \\ Institut Agama Islam Negeri (IAIN) Bukittinggi \\ tomihendra05@gmail.com
}

\begin{abstract}
The world of education at the present time is currently rife in competing to improve the quality of education. Various kinds of efforts they have made to improve the quality of education at all levels. Starting from the establishment of National Education Standards to increasing the accreditation of educational institutions. Communication as a means of improving the quality of education is an effort or one way to improve quality in the world of education. Experts agree that communication is needed in education. Therefore, good communication will form a good relationship. Whether it's the teacher with his students or students with his teacher. Teachers are required to play an active role in the teaching-learning process, especially in face-to-face teaching and learning process. Teachers are required as learning designers (designers of intruction), teachers as managers of learning (manager of instruction), teachers as instructors of learning, and teachers as counselors and so forth. In applying various things to the task of a teacher, the need for effective communication in the teaching-learning process between students and teachers. So that the goal of improving the quality of educational institutions can be achieved. In this study, the authors explain how important effective communication is in improving the quality of education. To belp the writer in describing the correlation between communication and education, the authors use descriptive qualitative methods
\end{abstract}

Keywords: Communication and Education

Abstrak. Dunia pendidikan pada saat sekarang kini sedang marak-maraknya memperlombakan peningkatan mutu pendidikan. Berbagai macam upaya yang mereka lakukan untuk peningkatan mutu pendidikan di semua jenjang. Mulai dari penetapan Standar Nasional Pendidikan sampai pada peningkatan Akreditasi lembaga pendidikan. Komunikasi sebagai sarana peningkatan mutu pendidikan merupakan upaya atau salah satu cara peningkatan mutu di dalam dunia pendidikan. Para ahli sepakat bahwa komunikasi sangat dibutuhkan dalam pendidikan. Sebab, komunikasi yang baik akan membentuk hubungan yang baik. Baik itu guru dengan muridnya atau murid dengan gurunya. Guru dituntut berperan aktif dalam proses belajar mengajar terutama dalam proses belajar mengajar tatap muka. Guru dituntut sebagai perancang pembelajaran (designer of intruction), guru sebagai pengelola pembelajaran (manager of Instruction), guru sebagai pengarah pembelajaran, dan guru sebagai konselor dan lain sebagainya. Dalam menerapkan beragam hal tugas seorang guru, perlunya komunikasi yang efektif dalam proses belajar mengajar antara murid dan guru. Sehingga tujuan peningkatan dari mutu di lembaga kependidikan bisa tercapai. Dalam penelitian ini, penulis memaparkan betapa pentingnya komunikasi yang efektif di dalam meningkatkan kualitas pendidikan. Untuk 
membantu penulis di dalam memaparkan korelasi antara komunikasi dengan pendidikan, maka penulis menggunakan metode kualitatif deskriptif.

Kata Kunci: Komunikasi dan Pendidikan.

\section{PENDAHULUAN}

Manusia merupakan makhluk yang tidak bisa lepas dari membutuhkan orang lain. Dalam hal tersebut manusia tidak dapat menghindari jika tidak berkomunikasi. Komunikasi merupakan proses penyampaian pesan atau informasi yang disampaikan oleh seseorang kepada orang lain agar bisa dipahami dan dimengerti. Komunikasi bisa berjalan dengan lancar apabila komunikator bisa memberikan pemahaman kepada komunikan dengan baik. Manusia merupakan mahkluk sosial yang harus berinterkasi dengan berkomunikasi yang baik dan benar.

Perkembangan zaman di era sekarang ini yang semakin meningkat, salah satunya perkembangan ilmu pengetahuan dan teknologi yang semakin hari semakin merubah peradaban dunia. Seperti halnya Menurut Marwah Daud Ibrahim beliau mensinyalir bahwa adanya perubahan potensi sosial yang cukup mendasar dan diharapkan perubahan ini bisa terjadi pada masyarakat akibat dari kemajuan teknologi komunikasi. (Dian Ismi Islami' 2013). Adanya kemajuan ini seharusnya peningkatan mutu pendidikan di Indonesia menjadi lebih mudah karena adanya sarana untuk meningkatkan mutu pendidikan diberbagai jenjang pendidikan.

Kebutuhan dari siswa yang harus dilengkapi oleh guru merupakan salah satu sarana untuk meningkatkan mutu di dalam dunia pendidikan. Salah satu sarananya ialah komunikasi antara guru dan muridnya bisa berjalan dengan lancar sehingga setidaknya salah satu upaya peninggkatan mutu pendidikan telah meningkat selangkah dari sebelumnya. Seperti halnya dalam proses belajar mengajar yang disampaikan oleh seorang guru kepada muridnya. Guru sangat berperan penting dalam penyampaian materi yang diberikan kepada muridnya agar dipahami dan dimengerti. Bukan hanya guru, 
murid juga harus ikut andil sehingga dengan begitu akan terciptalah komunikasi yang dinamis selama pembelajaran berlangsung. Para ahli sepakat bahwa komunikasi sangat dibutuhkan dalam pendidikan. Sebab, komunikasi yang baik akan membentuk hubungan yang baik pula. Baik itu guru dengan muridnya atau murid dengan gurunya.

Guru haruslah berperan aktif dalam proses belajar mengajar terutama dalam proses belajar mengajar tatap muka. Guru dituntut sebagai perancang pembelajaran (designer of intructionI), guru sebagai pengelola pembelajaran (manager of Instruction), guru sebagai pengarah pembelajaran, dan guru sebagai konselor dan lain sebagainya.(Hamzah, 2012, h. 22). Dalam menerapkan beragam hal tugas seorang guru, maka perlunya komunikasi yang efektif dalam proses belajar mengajar antara murid dan guru. Dengan begitu, maka tercapailah proses belajar mengajar yang efesien.

Dari penjabaran diatas, dapat dipahami bahwa komunikasi merupakan sebagai sarana pendidikan yang sangat dibutuhkan oleh setiap guru maupun murid demi terwujudnya peningkatan proses belajar mengajar yang efisien. Dalam hal ini penulis menggunakan metode deskriptif kualitatif berharap mampu menyelesaikan dan memberi solusi terhadap persoalan yang berkaitan dengan dunia komunikasi pendidikan.

\section{HASIL DAN PEMBAHASAN}

\section{Komunikasi}

Para ahli sepakat berpendapat bahwa ilmu komunikasi ialah termasuk kedalam salah satu ilmu sosial dan ilmu terapan. Karena ilmu ini memiliki sifat interdisipliner dan multidisipliner. Karena objek materilnya sama dengan ilmu-ilmu lainnya terutama sekali didalam ilmu kemasyarakatan. Sejarah mencatat bahwa komunikasi ada sesuai dengan peradaban manusia. Mulainya Allah swt. menciptakan Adam dan Hawa di muka bumi ini. walaupun hingga saat ini tidak ada bukti dokumentasi tentang corak komunikasi baik itu lambang, tanda-tanda dan lainnya. 
Menurut Everett M. Rogers (1986) pada bukunya Comunication Technology: The New Media in Society, menyebutkan bahwa komunikasi telah diperkirakan sejak abad ke 35.000 tahun SM. Pada zaman ini telah ada banyak ditemukan corak-corak komunikasi. Sehingga pendapat ini mengutakan bahwa komunikasi itu telah ada sejak lama sekali. (Rochajat Harun dan Elvinaro, 2012, h. 36). Komunikasi merupakan alat yang digunakan manusia untuk berinteraksi dengan orang lain. Dimana interaksi tersebut ada yang dua orang atau lebih, karena berinteraksi dengan orang lain adalah salah satu kebutuhan pokok manusia dalam kehidupan. Komunikasi merupakan bagian di mana kita hanya sekedar menyampaikan isi berita atau pesan kepada orang, tetapi juga menentukan hubungan kita dengan orang lain. Lewat komunikasi tersebut kita mampu untuk melakukan hubungan, mampu untuk saling menghargai dan saling melengkapi.

Komunikasi diistilahkan berawal dari pada pengertian communis yang memiliki arti membuat kebersamaan atau membagun kebersamaan antara dua orang atau lebih. Komunikasi juga berasal dari bahasa latin yaitu communico yang memiliki arti membagi. Dalam KBBI atau biasa di sebut kamus besar Bahasa Indonesia, komunikasi yaitu: pertama, mengirim atau menerima pesan atau berita kepada satu orang atau lebih hingga pesan tersebut tersampaikan dan dapat dipahami. Kedua, hubungan antara dua arah yang berbeda yaitu dari komunikator kepada komunikan saling bergantian memberikan informasi.( Muhammad Rajab, 2014) .

Sementara itu Carl L. Hovland berpendapat bahwa menurutnya, ilmu komunikasi adalah upaya yang sistematis untuk merumuskan secara tegas atas asas-asas menyampaikan informasi yang membentuk sebuah argumen maupun sikap. Dari definisi Hovald ini menggambarkan bahwa yang disajikan oleh ilmu komunikasi tidak hanya dipenyampaiannya saja melainkan juga membentuk sebuah pendapat umum dari masing-masing individu maupun sikap. Bahkan dari definisi khususnya Hovalnd mengungkapkan 
pengertian komunikasi yaitu bahwa komunikasi adalah proses mengubah prilaku orang lain (communication is the proces to modify the behavior other individuals).

Dalam berkomunikasi terdapat beberapa unsur-unsur yang saling berhubungan erat agar proses komunikasi tersebut dapat berjalan lancar. Adapun unsur-unsur tersebut sebagai berikut:

a. Harus memiliki sumber, yaitu seorang komunikator yang mempunyai informasi atau ide yang dapat diberikan baik dalam bentuk pendidikan maupun diluar bentuk pendidikan.

b. Ada suatu maksud yang hendak dicapai, komunikasi bertujuan untuk mempengaruhi sikap dan perilaku seseorang baik itu bersifat individu maupun kelompok. Jika tidak ada suatu maksud dalam komunikasi tersebut maka hal tersebut sebagai omong kosong belaka.

c. Adanya pesan atau informasi, pesan atau isi merupakan bentuk yang sangat diperlukan dalam menyatakan fakta, perasaan atau ide. Sehingga dengan adanya pesan atau isi tersebut dapat membangkitkan respon dari pihak komunikan. Tanpa adanya pesan maka komunikasi tidak bisa tersampaikan dengan efektif kaerena tidak adanya materi yang akan disampaikan.

d. Adanya media. Media sebagai bentuk saluran dalam menyampaikan informasi atau pesan. Dengan adanya media maka pesan yang disampaikan mudah.

e. Adanya penerima pesan. Penerima pesan sangat berperan penting dalam proses komunikasi. Apabila keempat unsur komunikas diatas terpenuhi, tetapi tidak ada penerima pesan maka proses komunikasi tidak terpenuhi dan tidak berjalan lancar. 
Dalam hal ini terlihat jelas bahwa komunikasi akan berjalan dengan baik dan benar, bila melengkapi unsur- unsur komunikasi, sebagaimana yang dipaparkan di atas.

\section{Pendidikan}

Setiap manusia di dunia pasti pernah mengalami dan menjalani proses pendidikan. Namun seringkali hanya menempuh pendidikannya saja lalu melupakan makna dan hakikat pendidikan yang sebenarnya. Hal ini disebabkan karena hanya menganggap pendidikan hanyalah suatu hal yang harus ditempuh bukan suatu hal kebutuhan. Maka dari itu makna dan hakikat dari pendidikan sering dilupakan.

Menurut Kamus Besar Bahasa Indonesia (KBBI), pendidikan berasal dari kata "didik"(mendidik). Menurut Prof. Brodjonegoro dalam Swarno mengatakan beberapa istilah pendidikan, yaitu: paedagogiek (ilmu menuntun anak), opvoeding (membesarkan), panggulawentah (mengubah), educare (melatih atau mengajar), dan ershicung (membangkitkan atau mengaktifkan). Dimaknainya bahwa pendidikan adalah tuntunan pada perkembangan manusia sejak lahir sampai kedewasaannya tercapai baik jasmani maupun rohani supaya dapat memenuhi kebutuhan diri dengan sendirinya. Secara luas menurut Prof. Lodge pendidikan adalah semua pengalaman yang didapat dari awal hidup sampai akhir hayat. Jadi dapat dipahami bahwa pendidikan memiliki makna suatu kegiatan yang dilakukan dengan sadar baik berupa pembinanaan atau pengajaran pikiran dan jasmani yang berlangsung sepanjang hayat demi meningkatkan keperibadiannya supaya bisa memainkan peranan dilingkungannnya pada waktu yang selaras dengan alam dan masyarakat.(Nanang Purwanto,2014, h. 19).

Berbicara mengenai pendidikan tidak lepas dengan sumber daya manusia (SDM). Sumber daya manusia yang handal adalah penggerak utama di dalam melestarikan dan menciptakan sumber daya alam (SDA) potensial yang bisa digunakan untuk kelangsungan hidup manusia. Menurut Muhamad 
Ilyasin beliau mengartikan pendidikan adalah upaya dalam mempersiapkan SDA yang memiliki keahlian sesuai dengan tuntunan pembangunan bangsa. Maka dari itu, perlunya kerja keras untuk menciptakan SDA dengan tujuan membentuk pribadi yang mandiri dan menyiapkan masyatakat yang terdidik sehingga menghasilkan kecerdasan intelektual, emosional, dan spiritual yang bersinergi dari yang satu dengan yang lainnya. Selain pandangan mengenai pendidikan yang dipaparkan di atas, berikut ini akan dikemukakan berbagai hakikat pendidikan disampaikan oleh para tokoh pendidikan. Hal ini bertujuan untuk memberikan pemahaman dan kesadaran dari diri sendiri akan arti pentingnya pendidikan bagi setiap manusia, baik itu pendidikan formal, pendidikan nonformal, dan pendidikan informal. John Dewey adalah seorang tokoh pembaharu pendidikan abad 20 yang memiliki aliran pendidikan progresif yaitu menempatkan pendidikan pada anak-anak agar pengetahuan terorganisasi dipelajari demi tujuan-tujuan tertentu yang lebih besar. Beliau mengatakan, menurutnya pendidikan merupakan proses pembentukan kemantapan fundamental dengan cara intelektual dan emosional kepada alam dan sesama alam.( Aas Siti Sholichah, 2018).

\section{Komunikasi dalam Sistem Pendidikan yang Efektif}

Pada dunia pendidikan proses belajar mengajar akan efektif, apabila komunikasi dan interaksi antara guru dan murid terjadi secara intensif terutama dalam proses belajar mengajar. Salah satu problem yang terjadi dalam pendidikan ialah kurangnya profesionalisme guru dalam mengajar sehingga membuat muridnya sulit untuk memahami pembelajaran yang diberikan oleh guru. Maka, guru disini memiliki pengaruh besar terhadap muridnya agar proses belajar dan mengajar bisa diterima dan dipahami secara efesien.

Dengan maksud guru tidak hanya menyampaikan saja tetapi harus merancang model-model pembalajaran yang senangi oleh muridnya. Sehingga muridnya bisa belajar secara optimal. Dalam proses belajar 
mengajar di dalam kelas proses komunikasi antara murid dan guru haruslah baik dan berlangsung baik serta selalu berkesinambungan baik antara murid dan guru ataupun sebaliknya yaitu guru dan murid. Materi yang disampaikan oleh seorang guru kepada muridnya merupakan proses komunikasi dalam belajar mengajar didalam kelas yang sering dipandang sebagai jantung atau inti kegiatan pembelajaran. Dalam interaksi atau komunikasi inilah terjadi interaksi edukatif yang berlangsung dengan pertukaran pesan yang tidak lain adalah materi pembelajaran. Namun, dalam konteks komunikasi guru adalah seorang komunikator karena dia merupakan pemimpin dalam pembelajaran berlangsung sedangkan muridnya adalah komunikan karena murid yang menerima materi yang di sampaikan oleh gurunya berupa pesan atau informasi. (Ety Nur Inah, 2015).

Komunikasi pendidikan bukan hanya dilakukan untuk saling tukarmenukar informasi saja. Akan tetapi adanya tujuan membangun dan memelihara relasi. Seperti dalam hal belajar mengajar yang dilakukan oleh guru kepada muridnya bukan hanya menyampaikan saja tetapi adanya dimensi relasi guru dan murid. Baiknya relasi guru dalam menyampaikan materinya akan membentuk proses pembelajaran yang efektif. Efektivitas pembelajaran sedikit banyak akan bergantung pada efektivitas komunikasi. Oleh karena itu, efektivitas seorang guru juga tergantung efektivitas komunikasinya dengan murid dalam pembelajaran baik itu di dalam kelas maupun diluar kelas. (Yosal Iriantara, Usep Syafrudin, 2013, h. 72).

Dalam menyampaikan pembelajaran seorang guru haruslah melakukan beberapa metode komunikasi dalam menyampaikan pesannya. Biasanya metode komunikasi dipahami sebagai teknik komunikasi. Agar pesan tersampaikan secara efektif. Seperti pemanfaatan media yang membuat suasana kelas tidak terlalu formal dan kebutuhan murid terpenuhi, yaitu dengan pemanfaatan media ini seperti menayangkan film pendek motivasi, maka guru bisa lebih dekat dengan muridnya dan mengetahui apa kebutuhan 
dari muridnya.( Yossita Wisman, 2017). Seperti halnya disalah satu sekolah, seorang guru memanfaatkan media youtube dalam mengambil penilaian kepada muridnya. Di sini murid dituntut untuk memiliki akun youtube lalu dimasukan konten-konten pembelajaran, seperti pembuatan video animasi percakapan dan lain sebagainya. Hal ini membuat para murid bersemangat dalam mempelajari, memahami dan mendalami mata pelajaran yang diberikan oleh gurunya. Selain kebutuhan para murid terpenuhi dan juga lamakelamaan akan terbiasa dan tidak merasakan kesulitan dalam menempuh proses belajar mengajar.

Seperti halnya yang diungkapkan Desmita di dalam Psikologi Perkembangan peserta didik, ia mengatakan bahwa peserta didik memiliki kebutuhan yaitu penghargaan demi membuktikan bahwa dirinya juga pantas diakui. Seorang guru dalam hal ini haruslah bersikap terbuka kepada semua muridnya dalam menyampaikan materi atau informasi di dalam kelas. Sikap yang seperti ini adalah faktor penting dalam menjalin komunikasi yang baik antara guru dan muridnya. Hal ini dapat terwujudkan apabila guru senantiasa bersikap terbuka pada murid dan merespon pendapat dari peserta didiknya. Tentunya sang murid akan merasa bangga apabila pendapatnya mendapat penghargaan dari sang guru berupa merespon tentang pendapatnya. Sikap yang saling terbuka dan menghargai ini merupakan bumbu-bumbu memperlancar arus komunikasi dan menciptakan hubungan yang baik antara guru dan murid. Karena peserta akan merasa lebih percaya diri sebab dapat bebas menunjukan/mengeluarkan apa yang ada didalam dirinya.(Abdul Aziz, 2017).

Maka dengan Keterbukaan yang diciptakan oleh guru terhadap muridnya, hali ini juga bisa mengetahui mana muridnya yang menyukai pelajaran ini dan mana yang tidak menyukai suatu pelajaran sehingga sang guru dapat mencari alternatif lain dalam proses belajar mengajar agar sang murid betah dengan pelajarannya. 


\section{Strategi Komunikasi Pendidikan}

Sebelum memasuki kepada strategi peningkatan mutu pedidikan maka perlu dipahami unsur-unsur penting dalam peningkatan mutu pembelajaran. Ada dua unsur penting dalam meningkatkan mutu pembelajara, yaitu sebagai berikut:

1) Pendekatan mikro pendidikan. Yaitu suatu pendekatan kepada indikator kajiannya dapat dilihat dari hubungan elemen dari murid, guru, dan interaksi antara murid dan guru dalam usaha pembelajaran. Secara lengkap elemen mikro yaitu pemberdayaan suatu pendidikan, kualitas manajemen, ketenagaan dan profesionalisme, kebutuhan dan relevansi.

2) Pendekatan makro pendidikan. Yaitu suatu kajian dengan elemen yang lebih luas dari mikro seperti Standarisasi pengembangan kurikulum, keadilan, persamaan dan pemerataan. (Moh. Saifulloh dkk, 2012).

Penulis mengambil pendekatan mikro sebagai bahan penelitian peningkatan komunikasi pendidikan. Sebab, Guru diibaratkan inti dari pendidikan (proses pembelajaran), sebab guru adalah orang yang berhadapan langsung dengan murid (peserta didik). Maka dari itu guru harus mampu bekerja dengan baik sehingga murid yang dihasilkan memiliki kompetensi yang sesuai dengan harapan. UU No. 14 tahun 2005 tentang Guru dan Dosen pasal 4 menegaskan bahwa guru sebagai agen pembelajaran berfungsi untuk meningkatkan mutu pendidikan nasional. untuk bisa melaksanakan tugas dan fungsi ini dengan baik maka seorang guru wajib memiliki syarat tertentu salah satunya kompetensi. Guru memiliki peran yang penting dan strategis dalam mendidik murid kearah, kematangan, kedewasaan, dan kemandirian. Dalam melaksanakan tugasnya guru tidak hanya bisa menguasi bahan ajar saja, akan tetapi guru harus memiliki kemampuan teknis edukatif dan memilliki keperibadian dan integritas pribadi yang bisa dicontoh sebagai teladan bagi muridnya.(Fadhli, 2017). 
Menurut ungkapan Locke, mengatakan bahwa model pembelajaran sangat berperan penting dalam penerapan cara pembelajaran yang modern dan konvensional. Teori belajar harus diperkuat agar dapat membantu guru dalam proses belajar mengajar yang efektif, efesien dan berkualiatas. teori belajar adalah pengembangan dari prilaku, kemanusiaan, pengetahuan dan sinektik. Teori ini berasal dari manusian belajar dari prilaku lalu dibentuk pengetahuannya sesuai dengan informasi atau pemaknaan dari masing-masing individu. Dari sinilah teori kognitif muncul yaitu pengetahuan memproses informasi yang diterima disimpan lalu diambil untuk menjadi bahan belajar. Dengan begitu maka timbullah metode belajar sebagai motivasi dalam diri untuk mencapai keberhasilan dalam pembelajaran yang memiliki sifat urgensi, kejelasan, pembangunan dan pendalaman. Metode pembelajaran ini adalah strategi untuk mencapai tujuan pembelajaran. (Emi Ratna Dewi, 2018).

Guru tidak bisa dikatakan sebagai mediator atau pengajar saja, namun guru juga harus mampu dalam melakukan pengawasan terhadap muridnya agar sang murid bisa belajar dengan baik. Pengawasan ini tidak hanya dilakukan di ruang kelas saja tetapi juga diluar kelas. Seperti mengayomi anak agar siswa tidak melakukan hal-hal yang tidak di inginkan. Jika kedapatan murid yang melakukan hal-hal tercela maka di sinilah peran guru mengayomi sang murid agar tidak melakukan hal tercela kembali. Guru memberikan alternatif positif berupa motivasi kepada muridnya agar terdorong tidak akan mau mengulangi kesalahannya. Bukan malah memarahi dan mengecamnya disaat itu juga. Maka dia akan merasa bertambah terpuruk dengan kesalahannya. (Abdul Malik, 2014).

Ada banyak cara yang bisa guru ambil sebagai strategi belajar mengajar baik di dalam kelas maupun diluar kelas. Berikut beberapa strategi guru dalam komunikasi pendidikan yaitu sebagai berikut (Ibid., Yossita Wisman): 
1) Seorang guru haruslah memiliki rasa empatik terhadap muridnya. Dengan memiliki kemampuan dalam memperoyeksikan diri kepada peranan orang lain maka seorang guru dapat merasakan apa yang dirasakan orang lain. Dengan begitu maka memudahkan seorang guru dalam menerapkan strategi komunikasi dalam proses belajar mengajar.

2) Menggunakan bahasa yang mudah dimengerti. Ada beberapa guru yang menggunakan bahasa yang sukar dimengerti oleh muridnya sehingga menjadi penghambat sampainya pesan kepada komunikan (siswa). Oleh karena itu menggunakan bahasa yang mudah dimengerti sangat penting dan berpengaruh terhadap efektivitasnya komunikasi pendidikan.

3) Selanjutnya guru harus bisa membuat seluruh murid dikelas bersikap aktif baik itu menulis, membaca, berbicara, dan lain sebagainya. Efektifnya komunikasi pendidikan sangat ditentukan dengan keaktifan pelajar dan pengajar dalam lokal. Dengan memberikan pertanyaan dan jawaban atau berupa perbuatan fisik maupun secara mental. Dengan adanya interaksi tersebut maka para siswa termotivasi dalam memperbaiki proses komunikasinya.

4) Guru harus menjadikan suasana kelas yang nyaman menjadi prioritas sehingga pembelajaran yang dipelajari memberikan keberhasilan dari keefektifan komunikasi pendidikan.

\section{PENUTUP}

Dalam peningkatan komunikasi pendidikan beragam cara yang bisa dilakukan oleh seorang guru dalam meningkatkan keaktifan dikelas baik berupa verbal maupun nonverbal. Tetapi didalam peningkatan mutu komunikasi pendidikan guru dituntut lebih dalam menciptakan keaktifan, kemahiran dan terdepan dalam proses belajar mengajar. Guru sangat menjadi ujung tombak dalam proses belajar mengajar, sebab gurulah yang membentuk muridnya jadi apa kedepannya. Oleh karena itu perlunya keterampilan seorang guru dalam menyampaikan materi. Seperti penjelasan diatas guru 
harus memanfaatkan menjadikan suasana kelas yang nyaman menjadi prioritas sehingga pembelajaran yang dipelajari memberikan keberhasilan dari keefektifan komunikasi pendidikan.

\section{DAFTAR REFERENSI}

Aziz, Abdul. (2017). Komunikasi Pendidik Dan Peserta Didik Dalam Pendidikan Islam. Media Kita. 1 (2).

Dewi, Erni Ratna. (2018). Metode Pembelajaran Modern Dan Konvensional Pada Sekolah Menengah Atas, Jurnal Ilmu Pendidikan, Keguruan, dan Pembelajaran. 2 (1).

Fadhli. (2017). Manajemen Peningkatan Mutu Pendidikan, TADBIR : Jurnal Studi Manajemen Pendidikan. 1 (2).

Harun, Rochajat dan Elvinaro Ardianto. (2012). Komunikasi Pembangunan Perubahan Sosial. Jakarta: Rajawali Pers.

Inah, Ety Nur. (2015). Peran Komunikasi Dalam Interaksi Guru dan Siswa, Jurnal Al-Ta'dib. 8 (2).

Iriantara, Yosal dan Usep Syaripudin. (2013). Komunikasi Pendidikan. Bandung: Sambiosa Rekatama Media.

Islami, Dian Ismi. (2013). Konsep Komunikasi Islam Dalam Sudut Pandang Formula Komunikasi Efektif. Wacana. 12 (1).

Malik, Abdul. (2014). Fungsi Komunikasi Antara Guru dan Siswa dalam Meningkatkan Kualitas Pendidikan. Jurnal Interaksi. 3 (2).

Purwanto, Nanang. (2014). Pengantar Pendidikan, Yogyakarta: Graha Ilmu.

Rajab, Muhamad. (2014). Jurnal Dakwah Tabligh. 15 (1).

Raswan, Tamyiz. (2017). Model Alternatif Pembelajaran Bahasa Arab Sebagai Bahasa Al-Qur'an. Journal Of Arabic Learning and Teaching. Lisanul Arab. 6 (1).

Saifulloh, Moh. Dkk. (2012). Strategi Peningkatan Mutu Pendidikan di Sekolah. Jurnal Sosial Humaniora, 5 (2).

Sholichah, Aas Siti. (2018). Teori-Teori Pendidikan Dalam Al-Qur'an. Jurnal Edukasi Islami Jurnal Pendidikan Islam. 7 (1).

Uno, Hamzah B. (2012). Profesi Kependidikan. Jakarta: PT. Bumi Aksara.

Wisman, Yossita. (2017). Komunikasi Efektif Dalam Dunia Pendidikan. Jurnal Nomosleca. 3 (2). 